\title{
Kohesivitas Kelompok dan Iklim Sekolah dengan Perilaku Agresi Pada Suporter Tim Sekolah
}

Ajeng Pradipta Fitriani

ajengpradipta98@gmail.com
Suci Murti Karini

Afia - Fitriani

Universitas Sebelas Maret Surakarta

\begin{abstract}
Aggressive behaviors is an abnormal behavior that is done by supporter. It occurs, for some factors, such as; group cohesion and school climate. Group cohesion is the attraction between group members. School climate is the quality of school life experience by someone. This research is aimed to knowing the correlation between group cohesion and the school climate with aggressive behaviors. The population of this research involving all the supporters of the sports team on SMAN Z Surakarta. This research using saturation sampling with data total are 51 data including 5 data outliers. The instruments to collect the data of the research were aggressive behavior scale (reliability 0,914), group cohesion scale (reliability 0,915) and school climate scale (reliability 0,875). The results showed the value of $p=0,009<0.05 ; R=0,442$, meaning there is a significant with moderate correlation between group cohesion and school climate with aggressive behavior.
\end{abstract}

Keywords: aggressive behavior, group cohesion, school climate

\begin{abstract}
Abstrak
Perilaku agresi merupakan perilaku menyimpang yang sering dilakukan oleh suporter. Hal-hal yang berperan pada munculnya perilaku agresi antara lain kohesivitas kelompok dan iklim sekolah. Kohesivitas kelompok ialah ketertarikan antar anggota kelompok. Iklim sekolah adalah kualitas sekolah berdasarkan pola pengalaman kehidupan sekolah seseorang. Penelitian ini bertujuan guna mengetahui hubungan antara kohesivitas kelompok dan iklim sekolah dengan perilaku agresi pada suporter tim olahraga SMAN Z Surakarta. Populasi dalam penelitian ini adalah seluruh suporter tim olahraga SMAN Z Surakarta. Penelitian ini menggunakan teknik pengambilan sampel jenuh dengan total sampel sebanyak 51 orang dengan 5 data outliers. Instrumen penelitian yang digunakan adalah skala perilaku agresi (reliabilitas 0,914), skala kohesivitas kelompok (reliabilitas 0,915) dan skala iklim sekolah (reliabilitas 0,875 ). Hasil penelitian pada kelompok kohesivitas dan iklim sekolah dengan perilaku agresi menunjukkan nilai $\mathrm{p}=0,009<0,05$ dan $\mathrm{R}=0,442$. Artinya terdapat hubungan signifikan yang sedang antara kohesivitas kelompok dan iklim sekolah dengan perilaku agresi.
\end{abstract}

Kata kunci: iklim sekolah, kohesivitas kelompok, perilaku agresi

Psikoislamika: Jurnal Psikologi dan Psikologi Islam (JPPI) Volume 16. Nomor 2. Tahun 2019. Copyright (C) 2019. Pusat Penelitian dan Layanan Psikologi.

\section{PENDAHULUAN}

Suporter merupakan bagian yang tidak terpisahkan dari olahraga. Adapun olahraga identik dengan adanya sebuah pertandingan. Ketiadaan suporter dalam suatu pertandingan akan membuat jalannya pertandingan terasa sepi, terasa hambar dan tidak bersemangat. Suporter merupakan orang yang datang untuk mendukung seseorang atau sekelompok orang dalam suatu tim olahraga. Dengan kata lain suporter adalah pecinta seorang atlet atau pun suatu tim olahraga. Biasanya suporter akan berteriak, melakukan yell-yell atau chant, menggunakan atribut yang sama dan berteriak menyemangati orang atau tim yang didukungnya.

Besarnya antusias dari masyarakat untuk menjadi suporter, berbanding lurus dengan banyaknya kasus kekerasan yang melekat pada suporter. Berdasarkan berita yang di kutip dari Firdausy (2018), terdapat sedikitnya 63 kasus kekerasan yang terjadi 
dalam kurun waktu 23 tahun terakhir. Kekerasan yang terjadi pada suporter ini tidak hanya melukai korbannya bahkan tidak sedikit suporter yang harus kehilangan nyawa karena kekerasan yang dilakukan oleh suporter tim lain.

Di Surakarta sendiri, perilaku agresi yang dilakukan oleh suporter olahraga terjadi pada September 2013. Kasus ini melibatkan siswa-siswi di salah satu SMA Negeri Surakarta yang selanjutnya akan disebut sebagai SMAN Z Surakarta. Mereka melakukan pengerusakan bangunan di sekolah lawan. Peneliti melakukan survei pendahuluan melalui penyebaran kuesoner dalam jaringan (daring) dan wawancara singkat dengan serta siswa yang menjadi suporter di SMAN Z Surakarta mengatakan bahwa menjadi suporter dapat meningkatkan rasa kekeluargaan dan kebersamaan hingga menjadi suporter dapat memberikan energi positif bagi pemain di lapangan. Selain itu, menjadi suporter dapat pula memunculkan rasa kebanggaan dalam diri mereka karena turut dalam mendukung prestasi SMA mereka.

Suporter SMAN Z Surakarta juga memiliki chant dan mereka menyanyikan bersama agar terciptanya rasa semangat dalam tim. Tetapi, dalam menjadi seorang suporter mereka tidak luput dengan adanya rasa kesal terhadap suporter tim lain, hal ini berdasarkan jawaban yang mereka berikan disebabkan oleh adanya provokasi, sikap sombong atau sok-sokan dari tim lawan sehingga menyebabkan tim suporter mereka menjadi emosi dan beberapa yang tidak dapat menahan emosinya menyebabkan perselisihan dengan suporter tim lawan.

Seorang guru di sekolah tersebut juga manyatakan bahwa dua sampai tiga tahun yang lalu, suporter SMAN Z Surakarta sempat terlibat dalam kasus pengerusakan mobil. Menurut penuturan guru tersebut, kejadian pengerusakan ini terjadi disebabkan oleh suporter yang merasa bahwa pengemudi mobil tersebut berperilaku sok saat melewati sekumpulan suporter dari SMAN Z Surakarta sehingga menyebabkan para suporter terpancing emosinya dan memutuskan untuk merusak mobil tersebut.

Siswa-siswi yang merupakan bagian dari suporter olahraga dari SMAN Z Surakarta ini secara tidak langsung telah melakukan perilaku agresi. Hal ini dapat dijelaskan menurut teori Bandura (dalam Myers, 2012) yaitu perilaku agresi diperoleh melalui pengamatan terhadap orang lain atau sekitarnya dan melalui pengalaman langsung. Faktor selanjutnya yaitu peristiwa-peristiwa yang mendahului seperti pengaruh contoh, bujukan dari orang lain, pengendalian instruksional dan kehadiran penonton; sehingga, individu yang berada dalam suatu kelompok suporter akan lebih mudah terbujuk untuk melakukan suatu perilaku agresi. Hal ini disebabkan karena individu dalam kelompok memiliki rasa keterikatan yang sangat besar atau yang biasa disebut dengan kohesivitas kelompok.

Kohesivitas kelompok akan memengaruhi satu individu dengan individu lainnya untuk menunjukkan tendensi manusia untuk berperilaku negatif seperti agresi dan mencuri. Hal ini telah daitemukan bahwa individu di dalam sebuah kelompok akan terinternalisasi oleh norma kelompok, memengaruhi penalaran moral termasuk agresi dan mencuri, dari mengikuti perilaku teman sekelompoknya (modelling) (Drew dan Braun, 2008).

Perilaku agresi yang dilakukan oleh siswa menurut Assegaf (dalam Umaroh, 2017) merupakan dampak dari sistem Pendidikan yang lebih mengutamakan pencapaian kognitif dan kurang dalam menekankan pada aspek afektif dalam diri siswa sehingga tidak terjadi keseimbangan di dalam sistem tersebut. Dalam penelitian multilevel analisis yang ditulis oleh Cornell dan Huang (2016) mereka menuliskan hubungan antara iklim sekolah dan penyesuaian siswa telah daitemukan pada masalah internal dan eksternal (Huang dkk., 2015; Kuperminc dkk., 2001), perilaku agresif dan masalah tingkah laku (Hawkins dkk., 2014; Henrich dkk., 2005), bullying dan agresi pada teman di sekolah (Cornell dkk., 2015), perilaku bunuh diri (Hatzenbuehler, 
2011) dan penyalahgunaan obat (Fletcher dkk., 2008). Walau pun banyak dari penelitian adalah korelasi dan crosssectional, ada penelitian longitudinal dan penelitian intervensi yang membuktikan kuatnya bukti dari adanya hubungan kondisi sekolah dan perilaku siswa yang berisiko (Kidiger dkk., 2011; Sznitman dan Romen, 2014).

Berdasarkan hal ini, peneliti akan melakukan penelitian mengenai Kohesivitas Kelompok dan Iklim Sekolah dengan Perilaku Agresi Suporter Tim Sekolah. Kohesivitas kelompok pada suporter tim olahraga akan dilihat dari semakin tinggi tingkat kohesivitas kelompok di dalamnya maka akan semakin besar kemungkinan para suporter untuk melakukan perilaku agresi. Selanjutnya, iklim sekolah dalam penelitian ini merujuk kepada semua fasilitas yang diberikan sekolah kepada suporter tim olahraga sekolah. Ketika sekolah memberikan suasana iklim sekolah yang positif maka perilaku agresi suporter akan rendah dan kebalikannya, apabila sekolah memberikan suasanya iklim sekolah yang negatif maka besar kemungkinan perilaku agresi suporter akan tinggi.

\section{METODE}

Jenis penelitian yang digunakan dalam penelitian ini adalah penelitian kuantitatif. Penelitian ini bertujuan untuk mengetahui hubungan antara perilaku agresi dengan kohesivitas kelompok dan iklim sekolah pada suporter olahraga SMAN Z Surakarta.

Populasi dalam penelitian ini adalah seluruh suporter aktif olahraga SMAN Z Surakarta yang berjumlah 51 subjek, dengan teknik pengambilan sampel jenuh, karena populasi pada penelitian ini seluruhnya dijadikan sampel penelitian. Teknik pengumpulan data penelitian menggunakan instrumen penelitian berupa kuisioner untuk Perilaku Agresi, Kohesivitas Kelompok dan Iklim Sekolah.

Perilaku agresi adalah tindakan yang dimaksudkan untuk melukai orang lain baik secara fisik maupun psikologi untuk mengekspresikan perasaan negatifnya sehingga dapat mencapai tujuan yang diinginkan Buss dan Perry (1992). Perilaku agresi pada penelitian ini akan diukur dengan skala perilaku agresi yang dimodifikasi dari Buss dan Perry (1992) yang meliputi empat aspek. Semakin tinggi nilai total, maka semakin tinggi tingkat perilaku agresi yang dilakukan oleh suporter. Alat ukur skala prokrastinasi akademik terdiri dari 38 aitem, dengan empat skala likert (1-4), dengan jawaban sangat tidak sesuai hingga sangat sesuai. Setelah dilakukan uji coba, diketahui seluruh aitem pada alat ukur adalah aitem yang valid dan memiliki nilai reliabilitas Cronbach alpha 0,914.

Cartwright dan Zander mengatakan pengertian kohesivitas kelompok yaitu merujuk kepada ketertarikan antar anggota kelompok dan adanya perasaan kepemilikan yang dirasakan oleh setiap anggota kelompok. Pada penelitian ini, skala kohesivitas kelompok akan dimodifikasi dari skala yang di buat oleh Nurul (2013) berdasarkan aspek-aspek yang dikemukakan oleh Cartwright dan Zander (1968). Alat ukur skala kohesivitas kelompok terdiri dari 35 aitem, dengan empat skala likert (1-4), dengan jawaban sangat tidak setuju hingga sangat setuju. Setelah dilakukan uji coba, diketahui seluruh aitem pada alat ukur adalah aitem yang valid dan memiliki nilai reliabilitas Cronbach alpha 0,915 .

Cohen, McCabe, Michelli dan Pickeral (2009) menjelaskan pengertian iklim sekolah sebagai karakter dan kualitas dari kehidupan sekolah dan berdasarkan pola pengalaman kehidupan sekolah seseorang yang merefleksikan norma, tujuan, nilai, hubungan interpersonal, proses belajar mengajar serta struktur organisasi. Skala iklim sekolah berdasarkan skala yang dibuat oleh dari Cornell (2017) yang didasari oleh tiga aspek. Alat ukur skala kohesivitas kelompok terdiri dari 25 aitem, dengan empat skala likert (1-4), dengan jawaban sangat tidak setuju hingga sangat setuju. Setelah dilakukan uji coba, diketahui seluruh aitem pada alat ukur adalah aitem yang valid dan memiliki nilai reliabilitas Cronbach alpha 0,875 
Pengujian hipotesis menggunakan analisis data regresi linier sederhana dengan menggunakan SPSS versi 22 dan untuk pengambilan keputusan pada penelitian ini menggunakan taraf signifikansi 0,05.

\section{HASIL}

Untuk menguji hubungan antar variabel dalam penelitian ini maka perlu dilakukan uji asumsi sebelum analisis data dilakukan dan berikut ini penjelasan beberapa uji asumsi dasar pada penelitian yang telah dilakukan.

Tabel 1. Hasil Uji Normalitas I

\begin{tabular}{lc}
\hline $\mathrm{N}$ & Sig. \\
\hline 51 & $.036^{\mathrm{c}}$ \\
\hline Berdasarkan tabel 1 dip
\end{tabular}

Berdasarkan tabel 1 diperoleh nilai Asymp. Sig. (2-tailed) sebesar 0,036 $(\mathrm{p}<0,05)$. Sehingga, peneliti melakukan uji outliers dan didapatkan 5 data merupakan outliers sehingga peneliti menghapus 5 data tersebut dan melakukan uji normalitas kembali.

Tabel 2. Hasil Uji Normalitas II

\begin{tabular}{lr}
\hline $\mathrm{N}$ & 46 \\
$\begin{array}{l}\text { Asymp. Sig. (2- } \\
\text { tailed) }\end{array}$ & $.200^{\mathrm{c}}$ \\
\hline
\end{tabular}

Berdasarkan tabel 2 diperoleh nilai Asymp. Sig. (2-tailed) sebesar 0,200 ( $>0,05)$. Artinya data terdistribusi secara normal. Sehingga, peneliti melanjutkan pada perhitungan selanjutnya.

Tabel 3. Hasil Uji Linearitas

\begin{tabular}{lc}
\hline Linearity & Sig \\
\hline Kohesivitas & .039 \\
Kelompok & .038 \\
Iklim Sekolah & \\
\hline
\end{tabular}

Berdasarkan tabel 3 diperoleh nilai Asymp. Sig. (2-tailed) antara kohesivitas kelompok dan perilaku agresi sebesar 0,039 ( $\mathrm{p}<0,05)$, oleh karena itu dapat disimpulkan bahwa, terdapat hubungan yang linear antara variabel perilaku agresi dan kohesivitas kelompok. Sedangkan pada variabel iklim sekolah dan perilaku agresi memiliki sig. sebesar 0,038 $(\mathrm{p}<0,05)$, sehingga dapat disimpulkan bahwa, terdapat hubungan yang linear antara variabel perilaku agresi dan iklim sekolah.

Tabel 4. Hasil Uji Multikolienaritas

\begin{tabular}{lrl}
\hline$R$ & $R$ Square & Sig. \\
\hline $.442^{\mathrm{a}}$ & .195 & $.009^{\mathrm{b}}$ \\
\hline
\end{tabular}

Tabel di atas memperlihatkan bahwa, nilai tolerance $0,982(\mathrm{p}>0,1)$ dan nilai VIF sebesar $1,019$ ( $\mathrm{p}<10)$. Hal ini dapat diartikan bahwa antar variabel bebas tidak terdapat masalah multikolinearitas.

Gambar 1. Hasil Uji Heteroskedastisitas

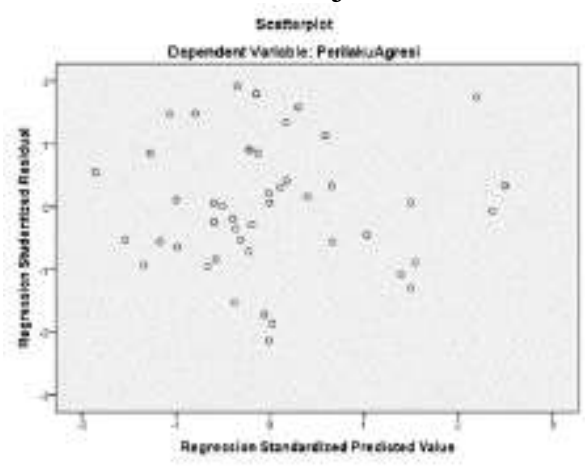

Bedasarkan gambar di atas, dapat diketahui titik-titik menyebar diatas dan dibawah angka 0 pada sumbu Y. Titik tersebut juga tidak membentuk suatu pola yang teratur. Sehingga disimpulkan bahwa, tidak ada masalah heterokedastisitas pada data penelitian ini.

Hasil uji autokorelasi menunjukkan nilai Durbin Watson (DW) sebesar 2,007. Kemudian hasil tersebut dibandingkan dengan dU. Subjek penelitian (n) yang digunakan sebanyak 46 subjek dan variabel prediktor (k) berjumlah 2. Berdasarkan tabel distribusi durbin warson diketahui nilai $\mathrm{dL}=$ 1,4368 dan nilai $\mathrm{dU}=1,6176$. Dari nilai tabel distribusi ini dapat diketahui bahwa nilai $\mathrm{dW}$ pada penelitian ini berada diantara dU dan (4$\mathrm{dU})$ yaitu 1,6176 <2,007 <2,3824. Sehingga, simpulan yang didapatkan adalah tidak terjadi masalah autokorelasi pada data penelitian ini.

Tabel 5. Hasil Uji Hipotesis

\begin{tabular}{lrr}
\hline & Tolerance & VIF \\
\hline Kohesivitas & .982 & 1.019 \\
Kelompok & .982 & 1.019 \\
Iklim Sekolah &
\end{tabular}


Berdasarkan tabel diatas, diketahui bahwa besarnya koefisien korelasi antara variabel perilaku adalah sebesar 0,442 dengan nilai Sig. 0,009 ( $p<0,05)$ dan berada pada tingkatan sedang. Artinya terdapat hubungan antara kohesivitas kelompok dan iklim sekolah dengan perilaku agresi pada suporter tim olahraga SMAN Z Surakarta.

Kategorisasi perilaku agresi pada subjek yaitu suporter tim olahraga SMAN Z Surakarta menyebar dari tingkat rendah $(60,9 \%)$, tingkat sedang $(39,1 \%)$ dan tingkat tinggi $(0 \%)$. Secara umum subjek memiliki tingkat perilaku agresi yang rendah dengan presentase $60,9 \%$ atau sebanyak 28 orang. Kategorisasi kohesivitas kelompok pada subjek yaitu suporter tim olahraga SMAN Z Surakarta menyebar dari tingkat rendah $(0 \%)$, tingkat sedang $(47,8 \%)$ dan tingkat tinggi $(52,2 \%)$. Secara umum subjek memiliki tingkat kohesivitas kelompok yang tinggi dengan presentase sebesar $52,2 \%$ atau berjumlah 24 orang. Dan kategorisasi iklim sekolah pada subjek yaitu suporter tim olahraga SMAN Z Surakarta menyebar dari tingkat kurang baik (0\%), tingkat sedang $(34,8 \%)$ dan tingkat baik $(65,2 \%)$. Secara umum subjek memiliki tingkat iklim sekolah yang baik yaitu dengan presentase $65,2 \%$ atau sebanyak 30 orang.

Sumbangan efektif kohesivitas kelompok terhadap perilaku agresi adalah sebesar 7,7\% dan sumbangan efektif iklim sekolah terhadap perilaku agresi adalah sebesar $11,8 \%$. Sehingga, jika di total sumbangan efektif yang diberikan oleh kedua variabel adalahsebesar 19,5\%.

Gambar 2. Jenis perilaku agresi yang dilakukan suporter

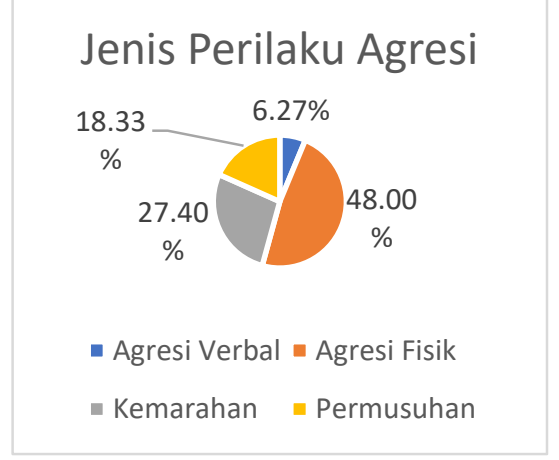

Berdasarkan diagram di atas dapat dilihat bahwa jenis perilaku agresi jika diurutkan berdasarkan perilaku agresi yang sering dilakukan ialah agresi fisik sebesar (48\%), kemarahan sebesar (27,4\%), permusuhan sebesar $(18,33 \%)$ dan agresi verbal sebesar $(6,27 \%)$.

Pada suporter yang merupakan siswa laki-laki mereka melakukan perilaku agresi sebesar $(33,78)$ dan siswa perempuan sebesar $(33,21)$. Taraf signifikansi equal variances assumed adalah 0,456 ( $p$ value > 0,05); signifikansi 2 tailed menunjukkan angka $0,817$ ( $p$ value $>0,05)$ dan nilai $t_{\text {hitung }}=0,223$ $\left(\mathrm{t}_{\text {hitung }}<\mathrm{t}_{\text {tabel }}\right) \mathrm{t}_{\text {tabel }}=1,684$; maka tidak terjadi perbedaan antar kelompok. Berdasarkan nilai signifikansi dan nilai t tersebut disimpulkan bahwa tidak terdapat perbedaan yang signifikan pada variabel perilaku agresi ditinjau dari perbedaan jenis kelamin suporter. Artinya baik suporter laki-laki mau pun perempuan sama-sama memiliki kemungkinan untuk melakukan perilaku agresi.

\section{DISKUSI}

Berdasarkan hasil perhitungan uji hipotesis didapatkan hasil bahwa hipotesis pada penelitian dapat diterima yaitu antara kohesivitas kelompok dan iklim sekolah memiliki hubungan yang signifikan dan sedang terhadap perilaku agresi.

Perilaku agresi yang dilakukan oleh sebagian besar suporter tim olahraga SMAN Z Surakarta ialah mudah marah, berkelahi, merusak barang, beradu argumen dan lain sebagainya. Di sisi lain, menurut suporter apabila mereka tidak diprovokasi terlebih dahulu terutama oleh suporter lawan, maka mereka tidak akan melakukan tindakantindakan yang negatif. Namun, apabila mereka mendapatkan provokasi oleh kelompok lain, maka untuk melindungi harga diri kelompok mereka akan melakukan tindakan agresi.

Myers (2012) dan Kings (2010) memberikan beberapa faktor yang dapat memengaruhi perilaku agresi seseorang, baik dari faktor psikologis, faktor biologis, faktor biokimia dan neurologis serta faktor sosio- 
kultural serta Fatima (2015) menyatakan faktor lainnya yang dapat memengaruhi perilaku siswa. Dari hasil penelitian, perilaku agresi suporter dapat meningkat dikarenakan faktor psikologis seperti peristiwa tidak menyenangkan, keterbangkitan dan sinyal, serta pengaruh sosial yaitu pengaruh kelompok. Selain itu, perkataan atau perbuatan dari orang lain merupakan penyebab paling kuat terjadinya perilaku agresi manusia (Baron \& Branscombe, 2011). Lalu, adanya kompetisi yang terjadi diantara dua kelompok juga dapat menimbulkan konflik (Baron, Byrne \& Suls, 1994 dalam Baron \& Branscombe, 2011). Fatima (2015) menyatakan bahwa hubungan yang buruk antara murid dengan murid atau guru dengan murid dapat meningkatkan perilaku agresi yang dilakukan oleh murid tersebut. Berdasarkan penjelasan di atas dapat diketahui bahwa saat suporter memiliki hubungan yang baik dengan sesama suporter serta tidak adanya provokasi dari kelompok lawan, maka hal-hal tersebut dapat menekan timbulnya perilaku agresi yang dilakukan oleh suporter.

Suporter dengan tingkat kohesivitas kelompok yang tinggi akan menunjukkan rasa solidaritas yang tinggi pula. Hal ini sejalan dengan penelitian yang telah dilakukan oleh Hutama (2015) serta Sunita (2010) yaitu terdapat hubungan positif antara kohesivitas kelompok dan perilaku agresi. Stein (1976) mengatakan bahwa, adanya ancaman dari luar dapat meningkatkan kohesivitas internal kelompok. Vasquez, Lickel, dan Hennigan (2010) mengatakan dalam penelitian mereka bahwa, kelompok dapat memengaruhi perilaku agresi seseorang ketika terdapat penurunan pada kendali moral sehingga memunculkan dorongan berperilaku agresi. Seseorang yang mendapatkan provokasi dari kelompoknnya akan cenderung untuk melakukan perilaku agresi. Ditambah dengan adanya desakan dari kelompok serta adanya identitas kelompok dapat memunculkan seseorang untuk melakukan perilaku agresi (Charters, Duffy \& Nesdale, 2013).

Johnson \& Johnson (2009) menyatakan sekolah yang memiliki tingkat kekerasan yang rendah memiliki siswa-siswi yang sadar akan peraturan dan memercayai bahwa peraturan tersebut adil serta siswa-siswi tersebut memiliki hubungan yang baik dengan gurunya. Cornell dan Huang (2016) mengatakan bahwa semakin baik iklim sekolah yang dirasakan oleh siswa-siswi, maka semakin kecil angka perilaku berisiko yang dapat mereka lakukan. Wang, Eccles \& Kenny (2013) mengatakan bahwa 'school structure support' (didefinisikan sebagai kejelasan dan kekonsistensian dari harapan guru) dan 'teacher emotional support' (didefinisikan sebagai tingkatan perhatian dan dukungan dari guru) dapat diasosiasikan dengan perilaku, emosi dan ikatan kognitif siswa.

Nilai $\mathrm{R}^{2}$ ( $\mathrm{R}$ square) dari hasil analisi regresi linear berganda pada penelitian ini dapat ketahui di bahwa variabel kualitas kohesivitas kelompok dan iklim sekolah secara bersama-sama dapat memprediksi variabel perilaku agresi sebesar 0,195 atau $19,5 \%$. Sisanya sebesar $80,5 \%$ dijelaskan oleh variabel atau faktor lain yang tidak termasuk di dalam penelitian ini misalnya saja fanatisme, suhu udara, hasil pertandingan dan lain sebagainya.

Berdasarkan dari hasil analisis didapatkan kategorisasi subjek memberikan gambaran rinci bahwa subjek penelitian ini memiliki perilaku agresi pada tingkat rendah, kohesivitas kelompok pada tingkat tinggi dan iklim sekolah pada tingkat yang baik. Sejalan dengan hasil uji hipotesis, gambaran mengenai kategorisasi ini menunjukkan bahwa kohesivitas kelompok jika digabungkan dengan iklim sekolah akan berperan dalam munculnya perilaku agresi. Semakin tinggi kohesivitas kelompok dan semakin buruk iklim sekolah akan membuat perilaku agresi semakin tinggi.

Analisis tambahan yang telah dilakukan didapatkan hasil bahwa perilaku agresi yang sering dilakukan oleh suporter ialah agresi fisik sebesar $(48,00 \%)$, kemarahan sebesar $(27,40 \%)$, permusuhan sebesar $(18,33 \%)$, dan agresi verbal sebesar $(6,27 \%)$. Hal ini sejalan dengan apa yang dikatakan oleh Baron \& Branscombe (2011) bahwa perilaku agresi 
lebih sering dilakukan face to face baik secara2. verbal maupun fisik.

Hasil analisis tambahan selanjutnya ialah perilaku agresi berdasarkan jenis kelamin, dapat disimpulkan bahwa tidak terjadi perbedaan yang signifikan antara perilaku agresi yang dilakukan oleh suporter perempuan maupun laki-laki Hal ini dapat dijelaskan oleh Baron \& Branscombe (2011) yang menyatakan bahwa, apabila tidak terdapat provokasi, maka signifikansi perilaku agresi laki-laki dan perempuan akan berbeda, dimana laki-laki akan lebih besar kemungkinan melakukan perilaku agresi. Namun, ketika adanya provokasi apalagi provokasi tersebut sangat intens maka perbedaan signifikansi akan hilang (laki-laki dan perempuan sama-sama memiliki kemungkinan yang besar untuk melakukan perilaku agresi).

\section{SIMPULAN DAN SARAN}

Berdasarkan hasil penelitian yang telah diperoleh, maka simpulan yang didapatkan ialah erdapat hubungan signifikan yang sedang antara kohesivitas kelompok dan iklim sekolah dengan perilaku agresi pada suporter tim olahraga SMAN Z Surakarta.3. Artinya semakin tinggi kohesivitas kelompok yang dimiliki suporter tim olahraga SMAN Z Surakarta, maka semakin tinggi perilaku agresi yang dilakukan oleh para suporter. Dan semakin buruk iklim sekolah maka akan semakin tinggi perilaku agresi yang dilakukan oleh suporter tim olahraga SMAN Z Surakarta.

Berdasarkan hasil penelitian yang diperoleh, maka dapat dikemukakan beberapa saran sebagai berikut.

1. Bagi Suporter

Suporter diharapkan mampu tetap mempertahankan dan meningkatkan sikap solidaritas serta kerjasama dan membawa sikap tersebut ke arah yang positif. Selain itu, suporter diharapkan lebih mampu bertindak realistis dan tidak mudah terpengaruh dengan teman maupun lawan untuk terpancing berperilaku agresi.

\section{Bagi Koordinator Suporter}

Koordinator suporter harus lebih mawas terhadap perilaku yang mungkin muncul pada kelompok suporternya baik karena rangsangan dari kelompok lain maupun dari hasil pertandingan. Koordinator suporter harus mampu memanfaatkan sikap kooperatif suporter dengan cara memberikan pemahaman kepada kelompok suporternya mengenai sanksi apa saja yang dapat diterima oleh suporter apabila melakukan tindakan yang merugikan baik ke kelompok, tim olahraga maupun ke sekolah. Koordinator suporter dapat memberikan peringatan berupa tidak boleh mengatakan hal-hal kotor, mengacungkan kepalan tangan, melempar barang, dan lain sebagainya kepada suporter saat mereka dalam pertemuan suporter diluar pertandingan. Koordinator harus menemukan suporter mana saja yang menjadi kunci tersulutnya emosi kelompok. Dengan memanfaatkan hubungan kerjasama yang baik, koordinator suporter harus mampu memberikan tindakan secara tepat dan cepat, bisa dengan cara mengeluarkan suporter tersebut dari dalam kumpulan kelompok untuk selanjutnya ditenangkan.

\section{BagiPihak Sekolah}

Untuk pihak sekolah diharapkan dapat melakukan pembinaan kelompok suporter. Hukuman berupa pembatasan kegiatan yang telah dilakukan oleh pihak sekolah tidak akan efektif apabila rangsangan negatif dari luar individu terlalu kuat. Pembatasan memang dapat membuat suporter lebih kecil kemungkinannya untuk bertemu dengan suporter tim lawan, namun sekecil apa pun kemungkinan pertemuan tersebut bila suporter tidak dapat mengendalikan diri, maka pembatasan kegiatan akan kurang efektif. Adanya hubungan yang baik antara guru dan suporter akan membangun komunikasi yang baik pula, hal ini dapat mempermudah pihak sekolah dalam mengikuti atau menghadiri kegiatan yang dilakukan suporter seperti pertemuan rutin suporter atau kegiatan lainnya. Pada saat pertemuan ini, pihak sekolah dapat hadir untuk memberikan pengertian serta pembinaan karater kepada suporter. Pihak 
sekolah dapat lebih berperan dalam http://www.tcrecord.org/Content.asp?Conten membentuk sikap individu ketika dihadapkan $\underline{\mathrm{t} I \mathrm{~d}=15220}$ diakses pada 18 Maret 2019. pada rangsangan agresi dari luar suporter, daCornell, D. (2017). The Authoritative School pihak sekolah dapat melakukan kerjasama Climate Survey and The School Climate dengan lembaga psikologi guna melakukan Bullying Survey: Research Summary. pembinaan karakter lebih lanjut, karena pada Virginia: University of Virginia. doi: setiap individu diperlukan pendekatan dan 10.13140/RG.2.1.4948.2325.

perlakuan yang berbeda satu dengan Cornell, D. \& Huang, F. (2016). Authoritative School lainnya.

4. Untuk Peneliti Selanjutnya

Untuk peneliti selanjutnya diharapkan mampu memperluas populasi penelitian agar hasilnya mampu digeneralisasikan secara Climate and High School Student Risk Behavior: A Cross-sectional Multi-level Analysis of Student Self-Reports. J Youth Adolescence, 45, 2246-2259. doi: 10.1007/s 10964-016-0424-3.

lebih luas. Selain itu, peneliti selanjutnyDrew, L. \& Braun, J. (2008). Running Head: dapat menambahkan atau menggunakan variabel bebas lainnya seperti pengaruh genetis; pengaruh budaya; pengaruh televisi, video games; kepribadian; hubungan dengan keluarga dan lain sebagainya untuk melihat dampaknya terhadap perilaku agresi. Peneliti Effect of Perceived Team Cohesion on Alcohol Consumption, Aggression and Cheating. Retrieved from https://psych.hanover.edu/research/thesis08/

BraunDrew2008.pdf diakses pada 18 Desember 2018.

selanjutnya harus dapat berkomunikasFatima, S. (2015). Cause of Students Aggresive dengan efektif sehingga mampu menjelaskan variabel penelitian terutama yang memiliki konotasi sensitif ketika mengajukan perizinan Behavior at Secondary School Level. Journal of Literature, Languages and Linguistics, 11, 49-65. doi: 2242-8435. penelitian.

Firdausy, F. (2018). Daftar Suporter Tewas dalam

\section{DAFTAR RUJUKAN}

Baron, R.A. \& Byrne, D. (2005). Psikologi Sosial Edisi Kesepuluh. Jakarta: Erlangga.
23 Tahun Terakhir. Retrieved from https://www.goal.com/id/berita/daftarsuporter-tewas-dalam-23-tahunterakhir/1f0zrfili4tyzzc7hwu2rp47v diakses pada 20 November 2018.

Baron, R.A., Branscombe, N.R. (2011). SocicHutama, G.G. (2015). Hubungan Antara Psychology $13^{\text {th }}$ edition. Boston: Pearson Kohesivitas Kelompok dengan Perilaku Education.

Buss, A. H. \& Perry, M. (1992). The Agression Questionnaire. Journal of Personality and Social Psychology, 63, 452-459. Johnson, D. W., Johnson, R. T. (2009). An Educational 10.1037/0022-3514.63.6.1011. Psychology Success Story: Social

Cartwright, D. dan Zander, A. (1968). Group Interdependence Theory and Cooperative Dynamics: Research and Theory $\left(3^{\text {rd }}\right.$ Edition). New York, Evanston and London: Harper \& Row Publishers.

Learning. Educatinal Researcher, 38, 365379. doi: 10.3102/0013189X09339057

King, L. A. (2010). Psikologi Umum: Sebuah Pandangan Apresiatif. Jakarta: Salemba Humanika. children's aggressive intentions. Journal cMyers, D. G. (2012). Psikologi Sosial Buku 2. Applied Developmental Psychology, 34(4), Jakarta: Salemba Humanika.

163-172. doi: 10.1016/j.appdev.2013.03.001Nurul, W. (2013). Hubungan antara Kohesivitas

Cohen, J., McCabe, L., Michelli, N. M., \& Pickeral, T. (2009). School Climate: Research, Policy, Practice and Teacher Education. Retrieved from
Kelompok Teman Sebaya dengan Perilaku Agresif pada Mahasiswa Fakultas Teknik Universitas Muslim Makassr. Skripsi. Makassar: Universitas Negeri Makassar. 
Stein, A.A. (1976). Conflict and Cohesion: A Review of the Literature. Journal of Conflict Resolution, 20, 143-172. doi: 10.1177/002200277602000106

Sunita, B. (2010). Hubungan Kohesivitas dengan Perilaku Agresi pada Anggota Geng Motor di Kota Medan. Skripsi. Medan: Universitas Sumatera Utara.

Umaroh, S. K. (2017). Agresivitas Siswa Ditinjau Berdasarkan Iklim Sekolah dan Keyakinan Normatif Mengenai Agresi. Jurnal Ecopsy, 4, 17-24. Retrieved from ppjp.unlam.ac.id/journal/index.php/ecopsy/ar ticle/view/3411 diakses pada 23 Agustus 2018.

Vasquez, E. A., Lickel, B., \& Hennigan, K. (2010). Gangs, displaced, and group-based aggression. Aggression and Violent Behavior, 15(2), 130-140. doi: 10.1016/j.avb.2009.08.001

Wang, M. T., Eccles, J. S \& Kenny, S. (2013). Not Lack of Ability but more Choice: Individual and Gender Differences in Choice of Careers in Science, Technology, Engineering and Mathematics. Psychological Science, 24. doi: $10.1177 / 0956797612458937$ 